\title{
The Effect Of Work Conflict And Job Stress On Employees Performance With Organizational Commitment As Intervening Variable
}

\author{
Rizky Budi Kurniawan ${ }^{1 *}$, R Andi Sularso ${ }^{2}$, Purnamie Titisari ${ }^{2}$ \\ ${ }^{1}$ Master of Management Program, University of Jember \\ ${ }^{2}$ Economy and Business Faculty, University of Jember \\ *rizaditya26@gmail.com
}

\begin{abstract}
Jatiroto Sugar Factory is the largest business unit owned by PTPN XI, the performance of Jatiroto Sugar Factory is the foundation of the company's survival because it has the largest sugar production capacity among other business units. This study aims to analyze the effect of work conflicts, work stress, organizational commitment and employee performance at Jatiroto Sugar Factory. This research is an explanatory research. The population in this study are employees of permanent status and has worked at least 2 years as many as 150 people. The results showed that : 1) Work conflicts have significant effect on organizational commitment of employees; 2) Work stress significantly influences organizational commitment of employees; 3) Work conflicts significantly affect employee performance; 4) Work stress had a direct but not significant effect on employee performance; 5) Organizational commitment has a significant effect on employee performance at Jatiroto Sugar Factory.
\end{abstract}

Keywords: Employee Performance, Organizational Commitment, Work Conflicts, Work Stress,

https://doi.org/10.26905/jmdk.v6i1.1985

\section{INTRODUCTION}

Jatiroto Sugar Factory is one business unit of PTPN XI with milling capacity reaching 8000 TCD (Ton Cane Day) operating in Lumajang Regency, East Java. As the largest business unit owned by PTPN XI, the performance of Jatiroto Sugar Factory is the foundation of the company's survival as it has the largest sugar production capacity among other business units. The higher the profit earned by Jatiroto Sugar Factory, the higher the profit of the company, and the lower the profit earned by Jatiroto Sugar Factory, the lower the company's overall profit.

However, the problem faced by Jatiroto Sugar Factory in the last three years is the decrease of profit of the company. This is influenced by the decline in employee performance caused by the conflict that occurs between employees. This conflict is caused by differences of opinion, attitude mismatch, goal difference in carrying out of the task. In addition, work conflicts are also reflected in almost every year there is a demonstration of employees, both on the distribution of bonuses and promotions that some employee thinks are less fair. Basically, conflict started when one party is made unhappy by the other about something that the first party deems important. The existence of different views among each person has the potential to cause friction, hurt and others. According to Robbins (1996) in the "Berhavior Organization" argues that conflict is a process of interaction 
that occurs due to a mismatch between the two opinions (perspectives) that affect the parties involved both positive and negative influences.

The conflict in one's work itself can cause stress to the parties involved. And the employees job stress at Jatiroto Sugar Factory is also a special issue, because employees feel themselves burdened with the company's target to achieve higher profits than the previous year. Job stress is a condition of tension that creates a physical and psychological imbalance, affecting the emotions, thought processes, and conditions of an employee. Stress has the potential to encourage or interfere with the execution of work, depending on how much stress it is. If there is no stress, work challenges also do not exist and work performance also tends to rise, but if stress has reached its peak then the work performance of employees will decrease, because stress interferes with the implementation of work, employees lose the ability to control stress resulting in not able to take decisions and irregular behavior (Rivai, 2009).

Organizational commitment is considered to be able to improve the employees performance in a company. The organizational commitment becomes an important thing in order to reach the goals that have been set. According to Robins (2008) argues that, "Commitment is a form of identification, loyalty and involvement expressed by employees against the organization or work unit". The success of a person's performance is determined by the level of competence, professionalism, and also his commitment to the work he is engaged in. Employees with high commitment will be more comfortable in working, faithful, participating so that will show optimal performance results. At Jatiroto Sugar Factory, employees' commitment to the company is that employees feel they need the company because their reliable livelihood is by working at Jatiroto Sugar Factory.

Performance is derived from the word job performance or actual performance which means work performance or achievement actually achieved by someone. Understanding the performance (work performance) is the work of quality and quantity achieved by an employee in performing its functions in accordance with the responsibilities given to him. Performance or performance is the result or output of a process. Based on research conducted by Devi (2009) on 64 Employees PT. Semeru Karya Buana Semarang showed that the conflict of work have a negative and significant impact on organizational commitment is evidenced by the probability value $<0.05$ which means there is a significant influence, conflict work negatively and significant to the employee's performance is evidenced by probability value $<0.05$ which means there is a significant influence, job stress has a negative and significant effect on organizational commitment is evidenced by the probability value $<0.05$ which means there is significant influence and organizational commitment have a positive and significant to employee performance is evidenced by the probability value $<0.05$ which means there is a significant influence.

Companies need to know the various weaknesses and advantages of employees as a foundation for maintaining organizational commitment and improve performance in the face of changes in the work environment. Companies must have performance indicators where employees and managers work together to plan performance to be done in the coming year, recognizing and finding ways to resolve problems. Organizational commitment is also required as an indicator of employee performance to establish a high level of competence, professionalism, and commitment to achieve optimal performance. Looking at the reality of work conflicts, job stress, employee commitment and the importance of employee performance for the company as a whole, the Jatiroto Sugar Factory management must always strive for the optimum performance of its employees. Hasibuan (2003) also explained that performance is the work 
achieved by a person in carrying out the tasks assigned to him based on his skills, experience, sincerity and time. With the influence of work conflicts, work stress and organizational commitment believed to have an effect on the performance of Jatiroto Sugar Factory employers raised the research with the title Influence Work Conflict And Work Stress Against Employee Performance With Organizational Commitment As Variable Intervening (Study on Employees PTPN XI, Factory Sugar Jatiroto, Lumajang).

The purpose of this study are mnbto analyze and discuss the influence of work conflict to organizational commitment of employees, analyze and discuss the influence of work stress on organizational commitment of employees, analyze and discuss the effect of work conflict on employee performance, analyze and discuss the effect of work stress on employee performance, discuss the effect of organizational commitment on employee performance at Jatiroto Sugar Factory.

\section{METHOD}

This research is an explanatory research that is research that explains the causal relationship and test the correlation between several variables through hypothesis testing or research. Explanatory research aims to analyze the relationship between one variable with other variables.

The population in this research is Jatiroto Sugar Factory employee which consists of 5 parts, namely: Plants, Technique, Processing, AKU and Quality Control. These employees are employees of class (II, III and IV) with the condition have been working for at least 2 years. The total number of permanent employees and working at least 2 years at Jatiroto Sugar Factory is 150 people. Which consist of Group 2, Group 3, and Group 4. The sample selection for this research is conducted by Proportioned Stratified Random Sampling. The analysis technique used is Structural Equation Modeling (SEM) by using AMOS (Analysis of Moment Structure) version. Variable in this research is : 1) Independent variable (independent) in this research is work conflict (X1) and work stress (X2); 2) The intervening variable of this research is organizational commitment is as intervening variable (Z); 3) Dependent Variable (Dependent Variable) in this research is employee performance $(\mathrm{Y})$.

The data collection in this research is questionnaire in the form of Likert Scale containing descriptive data and respondent's perception. It also used secondary data in the form of employee data. Data analysis was done by Structural Equation Modeling (SEM) technique using AMOS (Analysis of Moment Structure) 16.0 software program. The research was conducted at Jatiroto Sugar Factory, Lumajang District, East Java Province, while data collection was conducted in March-May 2017.

\section{Validity Test and Reliability Test}

Validity test is done by using confirmatory factor analysis in each latent variable. Each indicator used in both research variables has a loading factor greater than 0.50 . This means that the indicators used in this research variable are feasible or valid to be used as data collectors.

Calculation of reliability using composite (contruct) reliability with a cut off value of at least 0.70 . Each latent variable used in the study gives $\mathrm{CR}$ value above its cut-off value of 0.7 . So that can be said each reliable latent variable.

\section{Structural Equation Modeling Assumption Test}

Normality test results obtained the critical ratio value of 1.695 which is between -2.58 to 2.58 , so it can be stated that the data multivariate normal. In addition, the normal univariate data is indicated by all critical ratio values of all indicators located between $-2.58 \leq \mathrm{CR} \leq 2.58$.

The multicollinearity test result gives the determinant of sample covariance matrix of 144,921 . This value is far above the zero so it can be concluded that there is no problem multicollinearity and singularity in the data being analyzed. Outliers test results 
in this study shows the magnitude of Mahalanobis d-squared is smaller than Chi Square value at $(21,01,01)$ that is equal to 46,963. This means that in this study all cases did not experience outliers or can be said there is no significant difference between the data with the data group.

\section{RESULT AND DISCUSSION Instrument Validity Test Results}

Based on the results of validity test can be stated that the instrument of research which is an instrument that form the latent variable in this study, stated valid because each indicator has a value of loading factor greater than 0.50 . Where the values of the lowest indicator value of 0.547 and the highest of 0.892

\section{Reliability Test Results}

Based on the result of statistical test it can be stated that the reliability test results on latent variables in this study stated reliable with $\mathrm{CR}$ value above the cut-off value of 0.7 . Where the $C R$ value of the lowest variable is 0.875 and the highest is 0.943

\section{The Result of Structural Equation Model Analysis (SEM)}

SEM analysis is divided into four stages, namely the results of measurement model analysis, SEM assumption test, the results of structural model analysis and conformity evaluation model. The important assumptions that need to be tested in SEM analysis are: 1) normality, 2) outliers, and 3) multicollinearity.

\section{Normality.}

Normality test results show that CR value is 1.695 . It means the $\mathrm{CR}$ value is between -2.58 to 2.58 . So it can be stated that the multivariate data is normal. In addition the normal univariate data is indicated by all critical ratio values of all indicators located between $-2.58 \leq \mathrm{CR} \leq$ 2.58 .

\section{Multicoliner.}

The multicollinearity test result gives the determinant of sample covariance matrix of 144,921 . This value is far above the zero so it can be concluded that there is no problem multicollinearity and singularity in the data being analyzed.

\section{Outliers.}

The result of outliers test in this research shows that Mahalanobis d-squared value is smaller than Chi Square value at $\mathrm{n}=$ 27; $p=0,01$ that is equal to 46,963. This means that in this study all cases did not experience outliers or can be said there is no significant difference between the data with the data group.

\section{The Result of Structural Equation Modeling (SEM)}

Test results with the AMOS version 5.0 program gives the SEM model results as shown in the following figure showing the effect of work conflict and work stress on organizational commitment and employee performance of Jatiroto Sugar Factory :

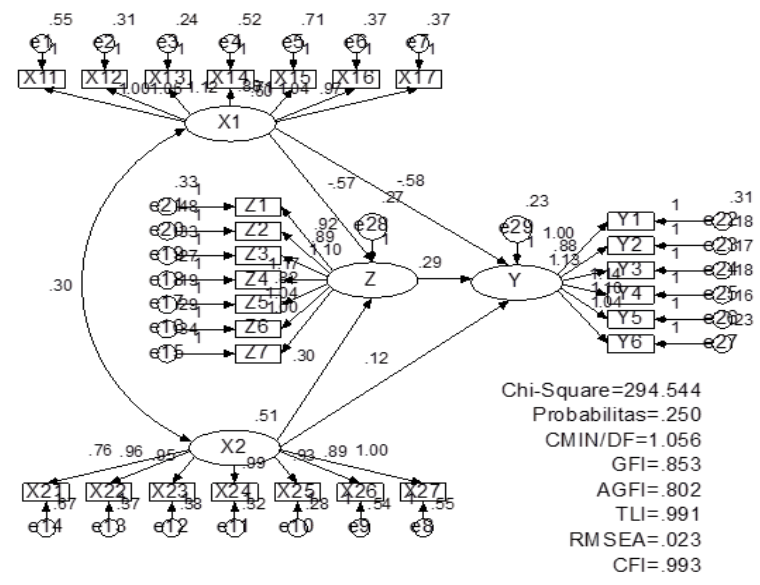

Picture 1. SEM Analysis Test

Source : Data processed ,2017

Furthermore, the Model of Conformity Test (Goodness of Fit Test) 
Tabel 1. SEM Conformity Index

\begin{tabular}{l|c|c|c}
\hline \multicolumn{1}{|c|}{ Criteria } & Cut Off Value & $\begin{array}{c}\text { Test } \\
\text { Result }\end{array}$ & $\begin{array}{c}\text { Informat } \\
\text { ion }\end{array}$ \\
\hline Chi Square & $\begin{array}{c}\text { Expected to be } \\
\text { smaller than X2 } \\
\text { at df }=279 \text { ie } \\
341.395\end{array}$ & 294,544 & Good \\
\hline Sig. Probability & $\geq 0,05$ & 0,25 & Good \\
\hline RMSEA & $\leq 0,08$ & 0,023 & Good \\
\hline GFI & $\geq 0,90$ & 0,853 & Marginal \\
\hline AGFI & $\geq 0,90$ & 0,802 & Marginal \\
\hline CMIN/DF & $\leq 2$ atau 3 & 1,056 & Good \\
\hline TLI & $\geq 0,95$ & 0,991 & Good \\
\hline CFI & $\geq 0,95$ & 0,993 & Good \\
\hline SOLICE Prin & & & \\
\hline
\end{tabular}

Source: Primary Data Processed, 2017

Next performed the Causality Test Tabel 2. Causality Test Result

\begin{tabular}{cccccccc}
\hline \multicolumn{2}{c}{ Influence } & Estimate & S.E. & C.R. & P P & Label \\
\hline Z & $<---$ & X1 & $-0,569$ & 0,119 & $-4,76$ & 0 & Sig \\
Z & $<---$ & X2 & 0,3 & 0,112 & 2,686 & 0,007 & Sig \\
Y & $<---$ & X1 & $-0,578$ & 0,13 & $-4,44$ & 0 & Sig \\
Y & $<---$ & X2 & 0,122 & 0,105 & 1,156 & 0,248 & Sig \\
Y & $<---$ & Z & 0,291 & 0,115 & 2,521 & 0,012 & Sig \\
\hline
\end{tabular}

Source: Primary Data Processed, 2017

\section{Discussion}

\section{The Influence of Work Conflict on Organizational Commitment}

The results of the study show that work conflict has a direct and significant effect on organizational commitment. Hence the hypothesis stating that the work conflict has significant effect on organizational commitment at Jatiroto Sugar Factory proved to be true or $\mathrm{H} 1$ accepted. This means that if the work conflict gets higher or increases, it will decrease organizational commitment. Conflict occurs due to individual problems of the employees themselves as well as problems in their daily work. Conflict is a psychological phenomenon experienced by someone who cause discomfort while working and can decrease employees' commitment to the company. Conflict is caused by organizational pressures in the workplace or a discrepancy between expectations and achievement of results. Organizational pressure arises when employees feel overwhelmed and unable to perform the task. According to Robbin (2008) Conflict affects employee behavior, such as the onset of work tension, increased work rotation, decreased job satisfaction, decreased organizational commitment and overall performance decline.

\section{The Influence of Job Stress on Organizational Commitment}

The results of the study showed that work stress had a direct and significant effect on organizational commitment. So the hypothesis stating that job stress has a significant effect on organizational commitment at Jatiroto Sugar Factory proved to be true or $\mathrm{H} 2$ accepted. This means that if work stress is higher or increased, it will increase organizational commitment. Job stress can affect the level of organizational commitment one has. Job stress experienced by employees can have a positive impact, as well as negative impacts for the concerned and for the organization or company. The results of this study prove that the stress of work in Jatiroto Sugar Factory can be interpreted positively. Positive aspects of work stress can be found when viewed from its usefulness and our willingness to use it. In this case, work stress is still in a proportional degree, the attitude of the constructive employees (build), and the transformation process that converts the potential energy from the original negative to positive positive energy. Employees see the stress pressure in Jatiroto Sugar Factory as a pressure or as a challenge. Challenge is something that encourages employees to answer it or move forward with it. This is different from pressure. Pressure is something that squeezes. By looking at the pressure as a challenge, it can be argued that stress is positive for the development of employees. Employees view stress as a positive thing which is then also addressed with positive things, and finally it is able to grow organizational commitment. 


\section{The Influence of Work Conflict Employee Performance}

The result of the study shows that work conflict has a direct and significant effect on employee performance. So the hypothesis that work conflict has a significant effect on employee performance in Jatiroto Sugar Factory proved to be true or H3 accepted. This means that if the work conflict is higher or increased, it will decrease employee performance. Conflict within an organization in certain conditions is very necessary to raise a healthy competing soul and enhance cooperation, but if the conflict that happens to run with excess will certainly be fatal that degrade employee performance. To the manager of Jatiroto Sugar Factory is recommended to respond to conflicts that occur in the environment as small as appaun the conflict. Conflict between prolonged sections can make the organization runs unhealthy and degrades employee performance. Conflicting employees become uncomfortable and unfocused in performing their duties because of the conflict that always weighs them. Based on arguments and research results above it can be concluded that the greater the conflicts that occur between parts can decrease employee performance and conversely conflict is also required but the smaller the conflict that occurred can improve employee performance. According to (Robbin, 1996) suggests that the relationship of work performance is "The relationship between conflict with corporate performance shows that, if the level of optimal conflict is the level of conflict is very functional then the performance will be maximized. If conflicts are too low, the performance of the company is stagnant or low and the company becomes slow in adapting to various environmental developments. If the level of conflict is too high, there will be constraints, uncooperative, and obstruct the achievement of the company's goals ".

\section{The Influence of Job Stress on Employee Performance}

The results showed that job stress had a direct but not significant effect on employee performance. So the hypothesis stating that job stress has a significant effect on employee performance at Jatiroto Sugar Factory is not proven or $\mathrm{H} 4$ rejected. This means that high or low job stress is not able to affect the performance of employees directly. In this case, the effect of work stress will only affect the performance of employees if through organizational commitment. Stress in relation to work can be high can be low and can affect a variety of factors. Working stress in a moderate level can improve employee performance, but high and low work stress can degrade the employee's performance. The stresses of relative stress on a person will depend on the person's ability to cope with work stress. Handoko (2001) states, stress can be helpful or functional, but also can play a role (disfunctional) or damage performance. This simply means that stress has the potential to encourage or interfere with the performance of the work, depending on how much stress it is. When there is no stress, work challenges are also absent, and work performance tends to be low. As stress increases, work performance tends to rise, as stress helps employees to direct all resources to meet various requirements or job requirements. It is a healthy stimulus to encourage employees to respond to job challenges. When stress has reached the "peak", which reflects the ability of daily employee execution, then additional stress will tend not to improve performance.

The relationship between job stress and employee performance is also explained by Robin (2008) stating that "much research has investigated stress-performance relationships. The most widespread pattern studied in the stress-performance literature is an inverted $\mathrm{U}$ relationship. "Further explained by Robbin (2008) the inverted U logic is that stress at low to moderate levels stimulates the body and improves the ability to react. At that moment the individual 
usually will be able to do his job better, more intensively, or faster. But if a lot of stress puts an unattainable demands or obstacles to someone, resulting in decreased performance. This inverted U-pattern also describes the reaction to stress over time, and to changes in intensity. This means that even moderate stress can have a negative effect on long-term performance because the sustained stress intensity undermines the individual and undermines its energy resources.

\section{The Effect of Organizational Commitment on Employee Performance}

The results showed that organizational commitment had a direct and significant effect on employee performance. So the hypothesis that the organizational commitment has a significant effect on employee performance in Jatiroto Sugar Factory proved to be true or H5 accepted. This means that if organizational commitment is better or improved, it will improve employee performance. Companies are required to be able to defend their employees to carry out the tasks that have been given and make employees still feel at home to work without degrading the employee's performance. The higher the commitment the more loyal employees to the company, so that will improve employee performance. Continuous performance increases will have an effect on the company's progress so that commitment is needed as an employee work indicator in order to work optimally in order to increase productivity and effectiveness of the company. Organizational commitment not only illustrates the passive loyalty of members of the organization but also the active action of members of the organization to provide the best for the organization so that the goals of the organization can be achieved and the sustainability of the organization can be maintained. Thus, the existence of organizational commitment is expected to improve organizational performance (Luthan, 1998). If associated with employee performance, normatively the emergence of high organizational commitment will lead to high retention rates so that employee performance is expected to increase.

Commitment is the driving factor of employees to work more diligently in order to improve employee performance. Commitment arises in every employee who is aware of the responsibilities that the company has given employees to run as well as possible. To give birth to a commitment to a job requires the willingness of the inside to like his work because of the love of the job that can motivate employees to do the job given to him wholeheartedly and will do the job as well as possible so as to get satisfactory results. Organizational commitment is a strong belief and support for the values and goals the organization wants to achieve.

\section{Conclusions}

Based on the results of the research, can be put forward the conclusion that work conflict significantly influence the organizational commitment of employees at Jatiroto Sugar Factory. This means that if the work conflict gets higher or increases, it will decrease the organizational commitment of the employees. Working stress has a significant effect on organizational commitment of employees at Jatiroto Sugar Factory. This means that if work stress is higher or increased, it will increase organizational commitment of employees. Work conflicts significantly affect employee performance at Jatiroto Sugar Factory. This means that if the work conflict is higher or increased, it will decrease employee performance. Job stress has a direct but not significant effect on employee performance at Jatiroto Sugar Factory. This means that high or low job stress is not able to affect the performance of employees directly. In this case, the effect of work stress will only affect the performance of employees if through organizational commitment. Organizational commitment has a significant effect on employee performance. This means that if the organizational commitment of employees is getting better or improved, it will improve 
employee performance. From the results of this study would researchers can provide suggestions, including: a). The results showed that work conflicts and job stress on employee performance either directly or indirectly through organizational commitment. Therefore, Jatiroto Sugar Factory should always pay attention to work conflicts and job stress, such as interdependence of tasks among employees, differences between employees, performance non-conformance, communication, pressure from superiors, task deadlines, value differences between employees and companies, and others. In order to improve overall employee performance. That will affect the increase in corporate profits in general, b). Or further research it is advisable to add other variables such as leadership style, education and training, organizational culture, work environment, and others. So as to obtain better findings in explaining the performance of the work and useful for the development of science, especially human resources management.

\section{REFERENCES}

Anwar Prabu Mangkunegara. 2008. Manajemen Sumber Daya Manusia Perusahaan, Remaja Rosda Karya, Bandung

Devi, E.K.D. 2009. Analisis Pengaruh Kepuasan Kerja dan Motivasi Terhadap Kinerja Karyawan dengan Komitmen Organisasional Sebagai Variabel Intervening (Studi Pada Karyawan Outsourcing PT Semeru Karya Buana Semarang. Tesis. Program Studi Magister Manajemen Undip Semaran., Tidak Dipublikasikan

Diana.A dan Tjiptono.F. 2004. Total Quality Management. Edisi Revisi. Yogyakarta: Andi

Ghozali, I. 2008. Structural Equation Modeling, Metode Alternatif dengan Partial Least Square. Semarang. Badan Penerbit Universitas Diponegoro
Handoko,T. 2001. Manajemen Personalia dan Sumber Daya Manusia. Yogyakarta: BPFE

Hasibuan, M.S.P. 2003. Manajemen Sumber Daya Manusia. Cetakan ketujuh. Jakarta: PT. Bumi Aksara

Luthans,F. 1998. Organizational Behavior, Seventh Edition. Boston: McGrawHill, Inc

Luthans, F. 2005. Organizational Behavior. New York: McGraw-hill

Mangkunegara, P. A. 2009. Manajemen Sumber Daya Manusia Perusahaan. Bandung: Penerbit PT. Remaja Rosdakarya

Robbins, S.P. 1996. Organizational Behavior Concept, Controversiest, Application. Eaglewoods Cliffs. Prentice Hall Inc

Robbin, S. P. \& Timothy A. Judge. 2008. Perilaku Organisasi, alih bahasa oleh Hadyana Pujaatmaka Salembat Empat, Jakarta

Vaitzhal Rivai dan Deddy Mulayadi. 2009, Kepemimpinan dan Perilaku Organisasi, Jakarta : PT Rajagrafindo Prasada. 